\title{
The cultural economy of British arts television: A case study on Artsworld channel (2002)
}

\author{
Menaka PP Bora ${ }^{1}$ \\ Goldsmiths College, University of London
}

\begin{abstract}
This article explores the relationship between the economics of arts broadcasting and cultural role of arts television in contemporary Britain. It presents part of a wider empirical study based upon the cultural economy of arts television conducted by the author in London. Here, 'arts television' is used as an umbrella term, which encompasses arts based television channels like Artsworld (principal case study in this article) and $B B C$ FOUR. The article examines the location of arts television in an emerging media culture of privatisation and digitalisation and examines what this means for the sustenance of arts television in Britain. It assesses the production culture of Artsworld channel within a market driven media industry and in doing so, focuses on the conflicting relationship between the commercial success and cultural success of arts television. The methodology includes qualitative research in terms of analysis of academic discourses, official documents, popular media theories, and personal interviews with arts broadcasters and directors of television channels.
\end{abstract}

Key words: arts television in Britain; cultural economy; market driven media industry; conflicting relationship; qualitative research.

1 Menaka PP Bora is a full-time researcher, performance artiste, choreographer and video film-maker based in London. She has an MA in Global Media and Transnational Communications at Goldsmiths College, University of London. Her research interests focus on arts broadcasting in Britain and India, South-Asian music television, politics of popular music and non-Western dance cultures. She is currently completing a PhD in Media and Communications at Goldsmiths College and lecturing in Cultural Studies at Kingston University, London. Email: m.bora@gold.ac.uk 
Resumo: Este artigo explora o relacionamento entre a economia da transmissão de arte pela TV e o papel cultural da televisão de arte na GrãBretanha contemporânea. Ele apresenta parte de um estudo empírico mais abrangente a respeito da economia cultural de televisão de arte, conduzido pela autora em Londres. Aqui, 'televisão de arte' é usado como um termo guarda-chuva, que abarca canais televisivos de arte, tais como Artsworld (principal caso estudado neste artigo) e BBC FOUR. $O$ artigo examina o lugar da televisão de arte numa emergente cultura midiática de privatização e digitalização e discute o que isto significa para a subsistência da televisão de arte na Grã Bretanha. Ele avalia a produção do canal Artsworld dentro de uma indústria midiática dirigida ao mercado, e, ao fazer isso, aborda o relacionamento conflitante entre sucesso comercial e sucesso cultural da televisão de arte. A metodologia inclui pesquisa qualitativa, em termos de análises de discursos acadêmicos, documentos oficiais, teorias da mídia de massa e entrevistas pessoais com exibidores televisivos de arte e diretores de canais de televisão.

Palavras-chave: televisão de arte na Grã-Bretanha; economia cultural; indústria midiática dirigida ao mercado; relacionamento conflituoso; pesquisa qualitativa.

Any understanding of culture and society must commence with a profound sense of historical processes, which have given birth to a particular moment or period of human consciousness. The relationship between arts and television has propelled numerous popular debates and discourses although few have done concrete academic research into 'arts television' in Britain. John A. Walker in his classic book, Arts TV: A History of Arts Television in Britain (1993) has celebrated television as a principal art form of twentieth century. But in this article television is not addressed as an art form. It is approached as a media form operating in a commercial broadcasting landscape. The contemporary television climate in Britain has links with its early historical climate. 
The present arts televisions scenario is shaped by a collage of both old and new cultural policies. It is surviving in a challenging and interesting media environment where arts broadcasters, shareholders and audiences are revolving around each other in the circuit of production. It is argued that television entertainment in relation to arts television in Britain is moving into an era of fierce competition and entreprenueralism where survival, in terms of a healthy and secure financial base is currently characterised by regular patronage from shareholders and investors and not merely by power of viewership.

\section{In Between: Cultural Location of British arts television}

While exploring the cultural location of arts television some of the noted media personalities of arts programmes like Philip Dodd, now ex-Director of Institute of Contemporary Arts (ICA) believe that arts television is currently located in a 'period of transition' between the, 'old world' and the 'new world' of television culture (Dodd, 2002). The 'old world' comprises of the post-World War II period where arts was special to people and television viewing was central to British ménages whereas the 'new world' is a sphere where arts is often challenged by science as a paradigm of rationalism. Arts television is yet to enter the sphere of the 'new world' where the concept of 'arts programmes' will be more 'complex' and demanding in terms of its content and quality (ibid.).

In the late twentieth century academic fields such as literary criticism, cultural studies and art history underwent a succession of theoretical transformations as a result of the influence of linguistics, semiotics, structuralism, Russian formalism, Marxism, Feminism, Black Studies, reception theory, psychoanalysis, and deconstruction (Walker, 1993). These new developments have also impinged upon the realm of television broadcasting through content and genres of different programme. In the transitional phase arts television not only needs to incorporate pedantic interpretations of art works, artists and art events, but also multidimensional perspectives of the entire cultural environment in which arts survive and operate in society. Popular criticisms on arts in the media often undermine the purpose of current arts programmes and anathemize the poor quality 
of arts programmes on television, leading to an uncertain status of exclusive arts television in contemporary Britain.

However, there are various other factors contributing towards an uncertain but challenging area of arts broadcasting which needs to be examined.

Figure 1.1 Cultural Location of Arts Television in Britain

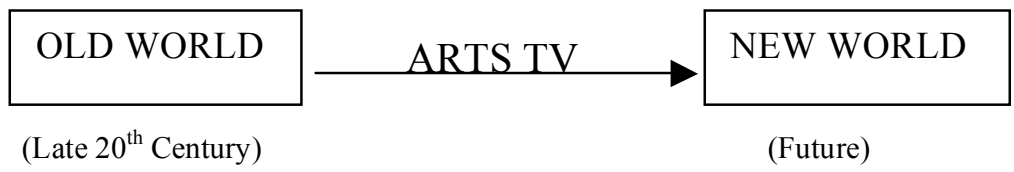

PERIOD OF TRANSITION

(Early $21^{\text {st }}$ Century)

Source: Primary Research based on personal interviews and media discourses, 2002

According to official statistics, arts programmes on television are popular although many argue that arts television is an unsuccessful phenomenon in television industry (Dodd, 2002). In its transitional phase, certain televisual arts programmes have succeeded in attaining higher percentage of audiences as compared to live arts attendances in Britain. Table 1.2 highlights the facts concerning television audiences of different arts genres and live arts audiences.

Table 1.2 Popularity of Televisual Arts Programmes

Percentage of Adult Population
\begin{tabular}{|l|c|c|}
\hline & $\begin{array}{c}\text { Television } \\
\text { Viewership }\end{array}$ & $\begin{array}{c}\text { Live } \\
\text { attendances }\end{array}$ \\
\hline Plays & 47 & 24 \\
\hline Operas & 11 & 7 \\
\hline Musicals & 25 & 19 \\
\hline Orchestral Music & 16 & 11 \\
\hline
\end{tabular}

Source: The Arts Council of Great Britain/Research Surveys of Great Britain, 1991.

Although there is a higher rate of terrestrial broadcasting viewership of arts programmes as compared to live events, the concept of niche arts television dedicated to only arts broadcasting is a problematical one. For example, Artsworld is a subscription-based arts channel and is currently facing uncertainties in terms of its longevity in the commercial television market. At this crucial stage of transition arts 
television is not only alarmed by future expectations of the 'new world' but also production restrictions and limitations in niche commercial climatic conditions. The transitional location of arts television can be studied from a theoretical location that epitomizes 'the third era of television' (Ellis, 2000a).

\section{At the end: Theoretical location of British Arts Television.}

Television industry has witnessed three eras of broadcasting in the later part of the twentieth century. The first 'era of scarcity' is characterized by a few channels broadcasting for selected parts of the day only until the late 1970s while the second 'era of availability' has spawned multiple channels broadcasting varied programmes through cable and satellite services (Ellis, 2000a).

The 'era of availability' is also called 'the third age of broadcasting' leading to expansion, diversification and de-regulation of broadcasting systems. The third 'era of plenty' in late 1990s soon opened a new market for galaxy of independent and commercial television channels to broadcast specialised programmes and indulge in healthy competition in Britain. The realisation of a 'commercial dream' has gained momentum through multiple choices, which undermine dependence on the schedules of terrestrial television transmission. The launching of digital television services in 1998 which offered alongside the existing broadcast and satellite channels a large number of subscription-based channels hitherto available only on cable, paved the way for new specialist channels such as channel 4's art-house channel Film Four (Ellis, 2000a). Television industry has diversified into different arenas of infotainment in the 'era of plenty' thus leading to 'plenty' of choices among the consumers.

Arts television is a product of the 'era of plenty' where viewers are free to choose any number of channels or programmes from the wide range of digital services at an extra cost. Its location in the 'era of plenty' characterised by 'narrowcasting' satellite television market which distinguishes the new interest-based channels like Artsworld channel and BBC Four from the older and general broadcasting' channels like BBC 1 and 2, ITV 1 and Channel 4.

In the 'era of plenty' location Artsworld channel operates within the wider context of a broadcasting ecology, which encompasses public service broadcasting 
corporations like $\mathrm{BBC}$ and other commercial satellite channels. It is pertinent to discuss BBC as an important support in maintaining the health of the cultural environment in which it operates.

Figure 1.3 Theoretical location of British Arts Television

ERA OF SCARCITY

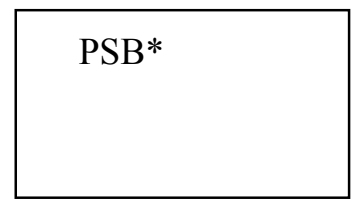

1920s-1980s

ONWARDS
ERA OF AVAILABILITY

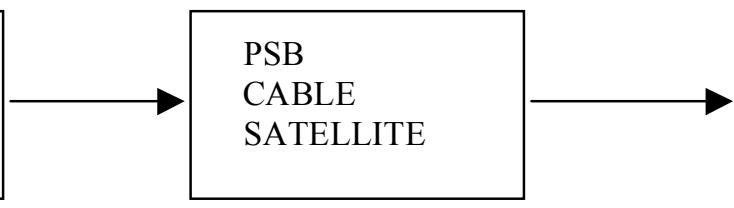

1980s-1990s
ERA OF PLENTY

PSB

CABLE

SATELLITE

DIGITAL

Note: $\quad$ * Public Service Broadcasting

Source: Based on data from Seeing Things, 2000

\section{BBC Vs. Commercial channels}

History reveals that $\mathrm{BBC}$ has experimented with arts programmes at the time when a number of real, experimental television transmissions took place in several countries in 1920 s and 1930s, which resulted in special commissioning of many classical ballets, and new dance forms in London for television. Some of the early arts programmes broadcast by $\mathrm{BBC}$ include $A$ Trip to the Seaside by English critic and artist, John Piper (early pioneer of arts television), Kenneth Clark's popular art quiz in 1937 and Monitor from 1958 to 1965 (Walker, 1993). From the beginning of television culture in Britain BBC has been regularly broadcasting arts programmes with the purpose of education, information and entertainment, which informs the principal raison dêtre of public service, broadcasting. Michael Jackson, head of music and arts of $\mathrm{BBC}$ believes that arts television has the particular strengths: firstly, making arts, which is generally available in London, accessible to everyone; secondly, acting as a culture patron particularly of contemporary work and finally, exploring the medium of television per se because 'television is the most important part of our culture' (Arts Broadcasting Discussion Document, 1991). The 'political correctness' of the official documents is, however, less relevant in the popular broadcasting ideologies. 
In the 'era of plenty', digital revolution has made an invaluable impact into lives of common people through digital television and interactive multi media broadcasting systems. The old Reithian concept of public service broadcasting is in a corrigible state. The process of change within public broadcasting is connected with other significant economic, political and structural developments, which at the very least will be seen to underline the integrity and power of public service broadcasting (Blumler, 1992). However, this does not imply that public service broadcasting principles are dead. 'Change' and 'adjustment' has become the new mantra of the communication age. For example, BBC has diversified its services and channels and is seen entertaining both commercial and interest-based programmes through digital services such as the launch of BBC FOUR in March 2002. BBC FOUR is the new television channel which is considered the biggest innovation in cultural broadcasting (BBC FOUR website). It is an arts-based channel broadcasting wide range of subjects in Britain. Herein, the focus is on BBC FOUR, an example of public service broadcasting that has transformed and adjusted into 'narrow casting' market of specialized interest-based television channels. The traditional ideals of public service broadcasting with special reference to mixed programming are gradually undermined with the advent of new technologies sweeping across millions at an affordable price. The idea of a public service system which would be devoid of any commercial or political motives and would have as its sole purpose the offering of a 'service' remains fragile and easily breakable (Tracey, 1998). However, it may be noted that broadcasting entails significant moral and intellectual questions and ambitions which are separate from any technological or financial considerations. Interestingly, the history of public broadcasting in general has been about efforts to create a new ideology based on political ideology and commercial need (Tracey, 1998).

The ideals of broadcasting have significantly changed from 'something for everyone' to 'everything for someone', which elucidates the growth of current interest-based channels because of digitalisation (Crisell, 1997). The proliferation of multiple channels in British broadcasting system has created a huge demand for content to fill them. Minority audiences with special interest have expressed their desire to be entertained and in such situation, the growth of arts television with 
particular reference to Artsworld and BBC FOUR is a significant phenomenon in the new media environment. The themed channels or the interest-based channels are new members of the television broadcasting community.

The location of commercial arts television with special reference to Artsworld channel is studied from a wider context of broadcasting ecology that encompasses public service broadcasting corporations. The 'era of plenty' informs post-modern ideals where change is inevitable and commercialisation is a necessary evil. It is an era where no certainties claim universal support and no theory can project a grand narrative into the future of broadcasting (Ellis, 2000a). The present television market is characterized by fierce competition, which is inevitable in the "era of plenty'. Even BBC, which is extolled for adhering to public service broadcasting rationale, is adapting itself to new changes and development. The BBC has outlined its intentions to:

\footnotetext{
Increase the financial contribution from out commercial activities....for those viewers who want to pay for even greater choice....BBC worldwide Ltd...will include themed subscriptions channels, a full range of multimedia and online products and eventually...programmes which can be ordered truly on demand. (Hall and Tabary, 1997).
}

It is believed that the revenue from licence fee is limited and therefore, in order to keep pace with the changing broadcasting climate it has formed into alternate ridges and grooves to strengthen its structure in the market. For example, BBC's new cultural avatar BBC FOUR is a commercial channel and is free to air only with a digital package. Increasing commercialisation is one of the many ways of serving minority or exclusive audience with specialist interest-based programmes or exclusive channels such as BBC FOUR. Earlier technology has been a limiting factor in addressing exclusive interest among common audiences. However, in the present decade advancement in scientific technology and awareness of different cultural manifestations has proved conducive to the birth and growth of specialist channels like Artsworld. Herein, although the 'era of plenty' promises new concepts, new approaches, new claims and new questions there are discrepancies in relation to level of competition and audience expectations. 


\section{Winners or Loses: Discrepancies in the era of plenty}

For television companies, it is an age of plenty in terms of income streams; for viewers, it is an age of plenty in terms of choices and subscriptions (Ellis, 2000). 'Plenty' of choices always come with a price ticket into the doorstep of consumers. Niche television entertains subscription channels rather than free entertainment. Moreover, the level of competition between the specialist channels is problematical in different layers. At one level, there is a fierce competition between exclusive channels of different genres for audiences in the television market. For example, Artsworld channel is one of the small channels catering to artistic taste buds and passions in the huge mosaic of multiple channels such as BBC FOUR (arts and current affairs based), Filmfour (film based), Sky Sports 1, 2, and 3 (sports based), Discovery (science and anthropology based), Sci-Fi (adventure based), UK Drama (television drama based), British Eurosport (sports based) etc. Most of these television channels are supported by subscriptions rather than advertising and so can address particular viewers. They take two forms: premium services and genre-defined branded services (Ellis, 2000). Through premium services many deal with material whose market value depends on 'newness' such as sports and films. Both films and sports events in general have maximum value at the moment in which it is being performed rather than the point of conclusion or outcome, unless as a 'classic' or a 'historic moment' (Ellis, 2000). For example, channels like Sky Sports and British Eurosport have universal appeal since they broadcast live sporting events and sports related programmes in Britain where majority citizens are famously known as dedicated sports fans. On the other hand, through genre-defined branded services, a single genre of programming is broadcast in myriad ways with special reference to arts channels like Artsworld. They may not have immediate market value but in the long-term, they have a perennial influence in the mind of art lovers and patrons. Herein, arts television is competing with not only with science or with film based exclusive television but also with other models of audio-visual communicating such as the video-recorder.

Video cassette recorders are used more frequently to record broadcast programmes off air than for playing back pre-recorded videos, which has enhanced viewers ability to match terrestrial television broadcast (Arts Council Discussion Document, 1997). From a problematical viewpoint video cassette recorders have 
offered possibilities to record existing broadcasting programmes, adjust time-sift capabilities, the chance to match the same recording many times, an alternative to rented or purchased tapes and the ability to show amateur, homes videos made with camcorders (Walker, 1993). As a result, subscription based arts television is often challenged by technologies such as video-recorders in 'the era of plenty'. Art video like Videola (1983) based on experimental works by video artists and musicians have potential to challenge many generalist arts programmes on British arts television (Walker, 2000). Videola is an art video that records new contemporary works of painters, performing and visual artists. It also records controversial works of art.

According to official statistics (Table 1.4) the percentage of households in the UK using video-recorders has steadily augmented since last decade. Interestingly, the percentage of households using video-recorders is much higher than those using satellite television networks.

Table 1.4 Percentage of households in the UK with home entertainment equipment

\begin{tabular}{|c|c|c|c|c|c|c|c|c|c|c|c|}
\hline YEAR & 1987 & 1988 & 1989 & 1990 & 1991 & 1992 & 1993 & 1994 & 1995 & 1996 & 1997 \\
\hline Television & - & - & 98 & 98 & 98 & 98 & 98 & 99 & 98 & 99 & - \\
\hline Satellite TV & - & - & 2 & 4 & 8 & 10 & 12 & 13 & 15 & 18 & - \\
\hline Video recorder & - & - & 60 & - & 68 & - & 73 & 77 & 79 & 82 & - \\
\hline Home computer & - & 19 & - & 21 & - & 24 & 24 & 25 & 27 & - & \\
\hline CD player & 5 & 9 & 14 & 24 & 31 & 35 & 43 & 56 & 66 & 73 & 75 \\
\hline Cassette player & 83 & 85 & 86 & 90 & 91 & 92 & 93 & 93 & 93 & 93 & 92 \\
\hline
\end{tabular}

Source: Office for National Statistics (1997) Living in Britain 1996: results from the 1996 General Household Survey; London: HMSO; British Phonographic Industry (1998), BPI Statistical Handbook London: British Phonographic Industry

The second level of competition is between homogenous television channels with particular reference to Artsworld and BBC FOUR. Increased competition due to increased choices in 'the era of plenty' has resulted in uncertainty of survival and development of the channels. According to popular media discourse the level of competition between BBC FOUR and Artsworld channel is not justified. John Hambly, the Chief Executive of Artsworld channels argues that 'BBC FOUR comes to audiences with all the huge advantages of a government-sanctioned, free-to-air BBC digital service, a half decent budget, good distribution and most important of all, no worries about revenue streams and all the cross promotion that money cannot buy 
(Hambly, 2002). On the other hand, Artsworld channel is a small company with limited financial back up from its shareholders and investors; it is struggling hard to survive in a stormy media climate affecting many big large and small media businesses.

The popular criticisms levelled against BBC FOUR throw light on the fact that $\mathrm{BBC}$ digital channels are about competition and only competition and not public service; this will reduce choice rather than expand it (Jeffries, 2002). BBC FOUR is believed to be lavishly financed by increased licence fees to compete 'unfairly and shamelessly with digital sector...alternate voices to the BBC are silenced for good (Artsworld website, 2002). However, even BBC FOUR with all its embellishments of secure financial base and marketing supports is struggling to maintain a sizeable slice of the national television audience.

According to James Marshall of BBC FOUR, 'it is tough to build audiences... it will take at least another two years to establish its identity in the market' (Marshall, 2002)2. This elucidates the fact that not all is green on the other side of the bank; even BBC FOUR has faced problems of audience creation and development, which remains a popular discussion between media producers and directors. One of the biggest problems faced by most channel media environment is 'how to get audience and how to keep them?' (Kabir, 2002)3. The issues arising out of audiences of arts television will be discussed in later chapters. Interestingly, Artsworld has been recently rescued from entering the digital graveyard comprising of unsuccessful arts channels like UK Arena and other exclusive channels like Money Channel, Carlton Food and Granada Breeze. Due to acute financial crisis, Artsworld had declared official closure of its television channel and website in early July 2002 until it was miraculously saved by one of its investors (Bateson, 2002)4. While pursuing the discussion of discrepancies in the era of plenty, cultural distance between different culture genres in society created by general opinion is taken into consideration.

\footnotetext{
${ }^{2}$ Email Interview with James Marshall, BBC FOUR, London, 2002.

${ }^{3}$ Personal Interview with Nasreen Munni Kabir, Director of Hyphen Films Ltd., London on 8 July 2002.

${ }^{4}$ Email Interview with Anna Bateson, Marketing Director, Artsworld Channel Ltd., London, 2002.
} 


\section{The problem of arts television}

Among the majority consumers of television, sports channels and film channels are more popular than other specialist interest like arts programmes since arts programmes are famously 'different' to understand. According to Nasreen Munni Kabir, producer of Hyphen Films Ltd, 'there is no demand for a 24 hour art channel at the moment....arts are a low priority... but arts programmes needs to be done'. It is a mythical concept that proves arts programmes on television are difficult to comprehend. In relation to traditional and contemporary arts, many argue against the notion that 'there is the generally inescapable feeling that there are cultural lumps plopped in the television soup to do you good' (Bragg, 1982:34). In reality musical arts programmes are often seen as 'highbrow' subjects drawn into a cocooned isolation of an elitist arts world. They appear to carry the cultural baggage of 'high culture', which alienates the majority working class from middles and upper class audiences. However, such corroboration is made less relevant in the light of current discourses elucidating blurred distinctions between so-called 'high culture' and 'popular culture'. Arts television in 'the era of plenty' stands out as a melting point of 'high' and 'popular' culture since television reaches out to a great number of audiences with a subscription fee. For example, Artsworld has had a monthly subscription of $£ 6$, for which audiences receive seventy hours of varied arts programming from the UK and around the world. Arts programmes need not be incomprehensible cultural artefacts of a post-modern era. A certain level of cultural awareness of availability of arts programmes specially commissioned for televisual productions will bridge the cultural distance between arts and majority audiences created by public opinion. However, the production of arts television is a problematical one with various layers of complexities added to its fabric.

Therefore, in the location sphere it is argued that exclusive arts television (a part of satellite television) is surviving in a notoriously changeable climate which is propitious for plenty of competitions not only between different audio-visual technologies and different ranges of interest-based commercial channels but also competition between homogenous genre of exclusive television with reference to principle case studies: Artsworld and BBC FOUR. There are no real winners or losers in the current 'plenty era' of competition. The journey is a difficult one with 
lots of commercial and cultural pressures in regards to arts television. Hence, in both 'cultural' and 'theoretical' locations, arts television is experiencing a heuristic state of existence.

\section{Behind the Screen: Role of Cultural Economy}

In order to fathom the profound relationship between economic and cultural spheres of arts television broadcasting cultural economy is taken into serious consideration. The vocabulary of 'cultural economy' is culled from critical excerpts of economy and culture theorized by duGay and Pryke (2002). Arts television is approached as a sphere where the boundaries of both culture and economy are blurred thus arriving at 'mutual constitution' of the two. Here, culture is reduced to one of its historical and conventional manifestations i.e., arts. Arts television is studied as a base for interaction between arts, broadcasters and audiences where culture of exclusive arts broadcasting is never divorced from politics and economics of general broadcasting principles and ideologies.

There is a certain level of contention of interests between broadcasters and viewers of arts television. Here, the term 'broadcasters' encompasses everyone involved in production including programme makers, directors and shareholders. For commercial channels, their business is to raise maximum dividends for shareholders leading to market success (Negrine, 1989). In order to survive the heat of competition between niche channels, there is a necessity for adequate financial support from shareholders and subscribers and also broadcasting of quality programmes which involves 'risk-taking.' In the case of Artsworld channel, the directors have taken risks of broadcasting exclusive arts programmes on television such as classical music and opera consistently for long periods of time. Moreover, they have also 'bought arts programmes from twentysix different countries belonging to Asia, Africa and Europe' in order to argue that 'arts is not a euro-centric speciality' (Melman, 2002). Investing huge amounts of money on different varieties of arts programmes such as The Royal Ballet of Cambodia - Time Regained, Monet and the Mediterranean, The Swan Lake, Sankai Juku : Shijima, Artist at Work, In Rehearsal etc, Artsworld has undermined success of branded arts programmes such as Omnibus and Arena on regular BBC schedules. However, this does not imply that 
Omnibus and Arena are unpopular or outdated arts programmes on British television. The exploration of different artistic genres and programmes undertaken by Artsworld is considered a cultural and financial risk in terms of investment, quality output and audience satisfaction. They have not relied on success of branded programmes of terrestrial broadcasting and has 'achieved something that no one in the last fifty years in Britain have ever achieved so far' (Melman, 2002).

Risk-taking is famously considered one of the most significant principles of path breaking or exclusive television channels. Many argue that there is a burning need to undertake risky productions and programmes on television, which may initially lack commercial success. In this context, Artsworld has retained its uniqueness by understanding financial risks of buying varied arts programmes without any secured audience satisfaction. As a result its commercial viability is under threat. In an official statement, Artsworld has had mentioned that it 'has not been able to secure the further funding necessary to continue operating' and thus, has decided to cease broadcasting from 31 July' (Artsworld website, 2002).

However, Artsworld is currently rescued from shrinking into a state of defunctness by one of its shareholders, BskyB until permanent sponsorship is gained for secured broadcasting base. BskyB is one of the biggest shareholders of digital television industry. Even support from BskyB facilitates an uncertain future for Artsworld. From the broadcasters perspective Artsworld is a market failure since its survival has become extremely uncertain; on the other hand, the viewers' perspective elucidates a successful channel since it has fulfilled most of its expectations. About $29 \%$ of the viewers have agreed that their expectations of the channel have been very well met and even those whose expectations have been well met would still like to see more classical music and opera on the channel (Artsworld Subscribers Research 2001). Others (71\%) have expressed their desire to watch more exclusive arts programmes on Artsworld.

Risk-taking is often not propitious for broadcasters although it may bring success in terms of quality programming and audience satisfaction. Artsworld channel did face severe commercial insecurity but viewers' discourses support its cultural success in bringing different varieties of arts programmes from different corners of the world into the television sets. Thus, the contention of interests 
between broadcasters and viewers is established in order to explore the complexities of production submits of arts television.

While pursuing the principal argument in the area of production, the role of shareholders and commercial advertising as an alternative to secured subscription is taken into serious consideration.

In television marketing climate, production of arts programmes involves relatively high amount of costs. While serving exclusive viewers with exclusive tastes and preferences it is vital to secure a strong financial base through consistent support from shareholders and investors. The sole income from subscription fee cannot meet the high amount of expenses involved in production and buying of arts programmes from different countries with reference to Artsworld. Artsworld Channels Ltd is an independent company whose shareholders include BskyB, Caledonia Investments, Guardian Media group and private investors. (Artsworld website). Withdrawal of regular financial support from Artsworld by its shareholders resulted in the official declaration of Artsworld's closure in the television market. As mentioned earlier, the life span of the arts channel has been almost cut short when investors and shareholders refused to meet the expenses of broadcasting to niche audiences. It has been brought back to air after one of its investors (BskyB) waived cost to allow broadcasting and thus, provide oxygen to the metabolism of Artsworld. So, the channel is 'running on a minimal budget while a suitable partner is looked for...if some sort of longer term financing is not secured the channel will still unfortunately have to close' (Bateson, 2002). Herein, the shareholders play a significant role in exclusive arts television. Without them broadcasting of arts programmes is almost impossible.

However, the role of shareholders or investors is further problematised in the light of publicly funded channels like BBC FOUR in the new digital television market. The press are of the opinion that the investors may refuse to finance more channels when the BBC is given 'limitless public money' to compete with them (Hambley, 2002).

Here, the focus of discussion is not on the investigation of reasons for refusal of finance by shareholders but on the fate of exclusive arts television in an uncertain 
media environment. In absence of secured economic resources from shareholders the focus shifts to that of the role of commercial advertising and sponsorship in sustaining good artistic programmes on arts television. Since BBC FOUR has began to dominate the digital television domain through broadcasting arts-programmes free of cost to license holders, it has become a commercial threat to private digital arts channels such as Artsworld, Performance and Digital Classics in the U.K. Digital Classics channel has been forced to change its strategy and become free to air in response to the challenges posed by BBC FOUR (Cullingford, 2002). In this context, Artsworld still remains a subscription-based channel and collaboration with commercial advertising and sponsorship remains imminent but uncertain.

\section{Additional means of support}

It is a matter of great concern that Artsworld has always underplayed the prominence of advertising in televisual broadcasting. According to recent production statistics, the time span of commercial advertising has been cut short from three and a half minutes to only two and a half minutes per hour of transmission (Melman, 2002). The ultimate intention is to provide uninterrupted hours of quality arts programmes to its viewers. Commercial breaks in between programmes are 'found irritating' among passionate viewers and hence are 'not essential' in between arts programmes. Earlier many specialist television channels have faced heavy uncertainties of broadcasting leading to closure, due to reliance on commercial advertising. Hence, Artsworld's famous policy is 'not to rely' on advertising and search for alternative funding or sponsorship from major corporate houses interested in covering spaces for arts patronage and publicity (Melman, 2002). This policy is however, not gaining momentum in the light of stormy media climate. With the channel's instability due to financial restrictions from its investors and limited subscription fees on account of being a niche product commercial advertising appears to be the most popular resort to sustenance.

The present scenario of arts television such as Artsworld channel is critical from cultural economist perspective. It is established that Artsworld is a specialist television product and in the current climate survival and maintenance is feasible in its location in a suite of channels owned by either Channel 4, Discovery or BBC 
(Bateson, 2002). Independent channels broadcasting exclusive arts programmes have become the biggest challenges of the digital world of communication. The content of arts television is revolving in a critical circuit of production subdivisions.

Fig 1.5 Internal Circuit of Production

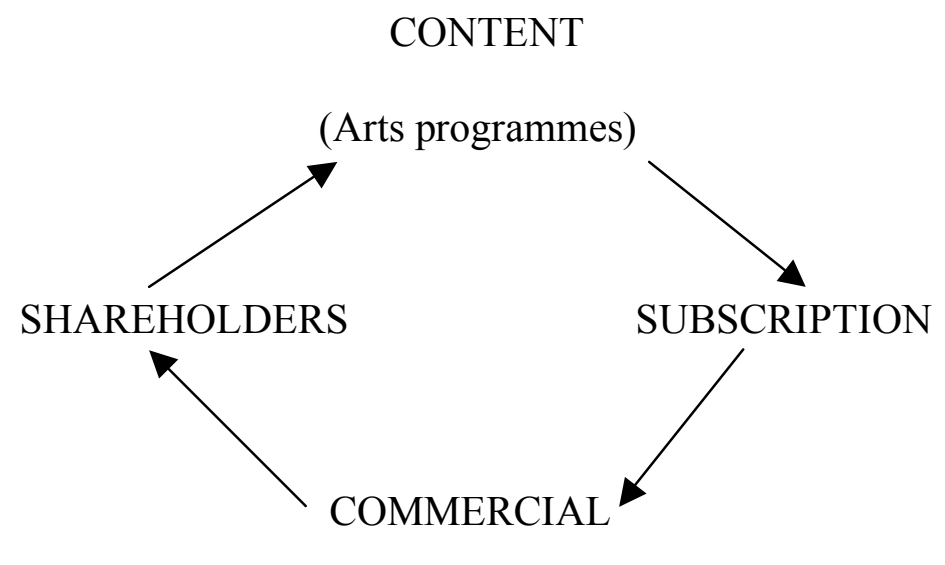

ADVERTISING

Source: Primary research based on personal interviews and media discourse, 2002.

In relation to Fig 1.5, it is argued that success of independent arts television like Artsworld depends not only on content of arts programmes but also on collaboration with shareholders and advertising and subscriptions. Deletion of any element from the internal ramification of production leads to a precarious state of existence. Presently, Artsworld is living at the mercy of shareholders and corporate sponsorship and as a result, the quality and unique identity of the channel is challenged. There is a creation of vicious circle of interdependence among the production subdivisions of arts television. Although each unit has its own prominence, the level of dependence cannot be undermined.

Making good television programmes and surviving independently are two contradictory factors of commercial television. In reality, commercial television exists to make money. The first obligation is to the shareholders, the second is to the advertisers and the third is to the audience (The Arts Council Conference Report, 1992). The commitment to 'quality' remains a remote possibility for most of the 
mainstream commercial channels. In the case of Artsworld, the illusion of commercial success at the cost of 'quality' programmes attributed to commercial channels is undermined. But it is gradually pulled into the dilemma of obligations, which determine the survival of any commercial channel. Ironically, Artsworld has been popularly considered a cultural success among viewers rather than commercial success among broadcasters. The critical question that arises out of this predicament is whether Artsworld can look out for alternate options outside the visions circuit of production and thus, remain quintessentially unique in exclusive television market.

Other plausible alternatives include existence in a group of established mainstream channels (example BBC FOUR) or support from autonomous funding bodies such as The Arts Council of England. The former underpins merging and cross promotion of independent channels with larger groups of channels which the later problematises the domain of commercial broadcasting.

\section{Role of autonomous funding bodies}

Today, the consensus within British television is that of commerce, co production and enterpreneuralism which can produce both good and poor television (Born, 2000). The role of Arts Council of England vis-à-vis art broadcasting in England is a problematical issue affecting the new television culture of digitalisation, commercialisation and narrowcasting. Under its charter the Arts Council of England is charged with developing and improving the knowledge, understanding and practice of the arts; and increasing the accessibility of the arts to the public throughout Great Britain using the medium of broadcasting (The Arts Council Discussion Document, 1991). It believes that arts programming helps to provide quality and choice for the consumer and urges the government to give further thought to the means by which it can be maintained and extended. Quality programming and increased competition in the production and transmission of broadcasting services are taken into particular consideration.

One of the recommendations of The Arts Council of England underpins financial assistance towards making of arts programmes for broadcasting, and proposes that the government invest additional funds from the levy on commercial television to help the new initiative. (The Arts Council's Response Report, 1989). 
However, in reality commercial digital arts channels like Artsworld have not received any funds from the council to make good arts programmes. Although recommendations have been made to support diversity of arts programmes on British television, commercial channels are remotely eligible for funding or commissions (Bateson, 2002). In such a context Artsworld's alternative sources of support remains highly uncertain. The official recommendations of The Arts Council of England has not succeeded in assisting commercial channels which are involved in making and broadcasting diverse genres of arts programmes to thousands of hoi polloi. The term 'minority interests' embraces complexities in the official framework of arts broadcasting. On one hand it gains popularity in the context of serving all interest groups in a democratic media environment; on the other hand it is officially criticized for entertaining cultural ghettos in society.

Officially, the concept of 'exclusive arts programming' on television is overturned by the concept of 'mixed programming' as a result of myopic vision. It has been argued that a future commitment to arts programming in the context of a mixed output of television programming upholding assimilation will maintain a broad audience for the arts which would not be delivered by other arrangements such as dedicated satellite channels (The Arts Council Discussion Document, 1991). The tendency is to underpin the processes of 'broadcasting' on terrestrial mixed television rather than 'narrowcasting' arts programmes on exclusion television. As a result, minority interests are never fulfilled in 'broadcasting' mixed programming. In the case of Artsworld channel, minority audiences are served through exclusive arts programming and thus, it establishes a vivid contradiction between aims and objectives of commercial narrowcasting and that of The Arts Council of England. The recommendations of providing spaces, for commercial channels and increased competitions remain valid only in theory but not in practice. The dilution of official recommendations is criticized in the wake of changing media climate characterised by diversification and not assimilation. At this stage the survival and future of exclusive arts television remains vehemently undermined but challenging. 


\section{Conclusion}

Overall, the findings of the research in the area of production of arts television indicate an interesting but challenging period of television broadcasting environment where 'uncertainty' and 'change' epitomizes the existence of niche television channels like Artsworld and BBC FOUR. The research has confirmed that in the cultural location of 'period of transition' and in the theoretical location of 'era of plenty' arts television with special reference to independent commercial channel is facing fierce conception with publicly funded digital commercial channels like BBC FOUR. Besides arts programming expands and contracts according to the state of economy: it is susceptible to any decline in television reverences (Walker, 1993). The present economic recession in media market has direct influence on arts television and as a result the arts budgets are often slashed down The subscription based Artsworld is challenged commercially and culturally to broadcast arts programmes without any subscription fee since BBC FOUR is free to those who embrace digital television package. As a result the mainstay of Artsworld channel has weakened with reference to shareholders and investors leading to an unstable and vulnerable state of survival.

Apart from tension between 'paid entertainment' and 'free entertainment; the area of production accommodates contentions between cultural and commercial success. It is located in a new broadcasting environment, which 'reflects the environment of political, commercial, sociological and moral pressures' (Bragg, 1982). Presently Artsworld is famously considered a cultural success in terms of fulfilling sociological pressures in making good arts programme, but a commercial failure in relation to economic limitations. In the commercial context, arts television has no special reservations; it is competing with other popular branches of entertainment. Hence, the shift from its representational location in mixed programming in terrestrial channels to exclusive programmes of arts programming through interest-based channels is drawing critical observations and arguments. While there is a need to expand the territory of niche audience the role of investors remains the prime target in securing a healthy base for arts broadcasting. 


\section{References}

Artsworld Subscriber Research (2001-2) London: Artsworld Channels Ltd.

Bateson, A. (2002) E-mail Interview. London: Artsworld Ltd.

Benjamin, W. (1991) The Work of Art in the Age of Mechanical Reproduction. In Arendt, H. (ed) Illuminations. London: Pimplico.

Blumler, J.G. (1992) Television and the Public Interest. London and New Delhi: Sage.

Boddy, W. (2002). Television in Transit, Screen, Vol. 41 No.1. Oxford: Oxford University Press.

Bora, M. P.P. (2002) Arts in the Mediascape: Television, Arts and Cultural Economy. M.A. Thesis. Department of Media and Communications, Goldsmiths College: University of London.

Born, G. (2000) Inside TV: TV Studies and the Sociology of culture. Screen, Vol. 41 No.4, Glasgow: Oxford University Press.

Bourdieu, P. (1993) The Field of Cultural Reproduction. Cornwell: Polity Press.

Bragg, M. (1982) Open space for Arts. In Wenham, B.(ed) The Third Age of Broadcasting. London: Faber and Faber.

Corner, J (ed) (1991) Popular Television in Britain: Studies in Cultural history, London: BFI.

Crisell, A. (1997) An Introductory History of British Broadcasting. London and New York: Routledge.

Curran, H. and Gurevith, M. (eds) (1991) Mass Media and Society. London: Arnold.

Dodd, P. (5 July 2002). Personal Interview. London: ICA.

Du Gay, P. and Pryke, M. (2002) Cultural Economy. London and New Delhi: Sage.

Ellis, J. (2000a) Seeing Things : Television in the Age of Uncertainty. London and New York: I.B. Tauris.

Ellis, J. (200ob) Scheduling: The last creative art in Television? Media, Culture and Society, Vol. 22:25-28, London and New Delhi: Sage.

Fiske, J. (1978) New Accents: Reading Television. London: Matheun and Co. Ltd.

Fiske, J. (1987) Television Culture. London and New York: Routledge.

Garnham, N. (2000) Emancipation, the Media and Modernity: Arguments about Media and Social Theory. New York : Oxford University Press.

Habermas, J. (1989) The Structural transformation of the Public Sphere: An Inquiry into the Category of Bourgeois' Society. Great Britain: Polity Press.

Hall, S. and Tabary, T. (1997) On Television. London: Plato Press.

Hambly, J. (2002) Dominating the Digital Domain. Broadcast, 22 February, 1-7.

Harvey, D. (1990) The Condition of Post Modernity. Oxford: Blackwell 
Hay, J. (2001) Locating the Televisual, Television and New Media, Vol. 2, No.3, London and New Delhi: Sage.

Hazard, P.D. (ed) (1966) TV as Art. Illinois: National Council of Teachers of English.

Jeffries, S. (2002) Betrayed by the Beeb, The Guardian: Saturday Review, 2 March, 4.

Jordan, S. and Allen D. (ed) (1993) Parallel lines: Media Representations of Dance. London Libbey and Co. Ltd.

Kabir, N. M. (2002) Personal Interview. London: Hyphen Films Ltd.

Marshall, J. (2002) E-mail Interview. London: BBC FOUR.

McLaughlin, C. (1989). The Art of Television: Arts Programming and its Audience Research Report. London: Independent Broadcasting Authority.

Melman, R. (2002) Personal Interview. London; Artsworld Channels Ltd.

Morley, D. (1992) Television, Audiences and Cultural Studies. London and New York: Routledge

Neale, S. (2002) Genre and Hollywood. London: Routledge.

Negrine, R. (1989) Politics and the Mass Media in Britain. London and New York: Routledge.

Philips, S. (1991) Arts Broadcasting Discussion Document. London: National Arts and Media Strategy Unit.

Robins, K and Morley, D. (1995) Spaces of Identity. London and New York: Routledge.

Rose, B. (1992) Televising the Performing Arts. London: Greenwood Press.

The Arts Council of England (1989) A Summary of The Art Council's Response to the White Paper on Broadcasting. London: The Arts Council of England.

The Arts Council of England (1991) The Arts Council's Response to The Future of BBC: A Discussion Document. London: The Arts Council of England.

The Arts Council of England (1992) Odd Couple: Broadcasting and Arts. London: The Arts Council of England

Thompson, J. (1995) The Media and Modernity: A Social Theory of the Media. Cambridge: Cambridge University Press.

Thussu, D.K. (ed) (1989) Electronic Empires: Global Media and Local Resistance. London: Arnold.

Thussu, D.K. (2000) International Communications: Continuity and Change. New York and London: Oxford University Press.

Tongue, C. (1996) The Future of Public Service Broadcasting in a multi-channel digital age: A Report. London: The Arts Council of England.

Tracey, M. (1998) The Decline and Fall of Public Service Broadcasting. Oxford and New York: Oxford University Press. 
Turner, G. (2001) The Uses and Limitations of Genres In Creber, G. (ed) The Television Genre Book. London: FEJ.

Walker, J.A. (1993) Arts TV: A History of Arts Television in Britain. London: John Libbey and Co Ltd and The Arts Council of England.

Welsh, M. and Tibbetts J.C. (1999) Television and History: A Report from XVIIIth IAMHIST conference, Leeds, Historical Journal of Film, Radio and Television, Vol. 20:1. Oxon: Carfax and Taylor Ltd.

Wiles, D. (2002) Personal Interview. London: Granada Media Ltd.

Williams, R. (ed) (1989) Selected Writings in Television. London and New York: Routledge.

Wober, J.M. (1990) Interests in Arts on Television: A Report. London: Independent Broadcasting Authority.

\section{Internet sources}

Billington, M. (2001) Is there anybody out there? The Guardian Arts. June 26 http://www.guardian.co.uk/arts.story/0,3604,512537,00.html (29 July 2002)

Cullingford, M. (2002) Artsworld to cease broadcasting. Gramophone. July 11 <http://www.gramophone.co.uk/newsMainTemplate.asp?storyID=1225\&new $=6>$ ( 9 August 2002).

Dyke, G. (2002) BBC's challenge in the digital age. Guardian Unlimited July2 <http://mediaa.guardian.co.uk/edinburghtvfedtival/story.0,7523,363309,00.

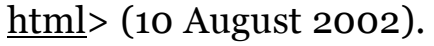

